\title{
Multidrug-Resistant Disseminated Nocardia Farcinica Infection in a Systemic Lupus Erythematosus Patient
}

\author{
Sistemik Lupus Eritematöz Hastasında Çoklu İlaç Dirençli Yaygın \\ Nokardia Farcinica Enfeksiyonu \\ Öztürk ATEŞ, ${ }^{1}$ Havva CİLAN, ${ }^{1}$ Sema OYMAK,,${ }^{2}$ Orhan YILDIZ, ${ }^{3}$ Oktay OYMAK ${ }^{1}$ \\ ${ }^{1}$ Department of Nephrology, Medical Faculty of Erciyes University, Kayseri, Turkey \\ ${ }^{2}$ Department of Pulmonary Medicine, Medical Faculty of Erciyes University, Kayseri, Turkey \\ ${ }^{3}$ Department of Infection Disease, Medical Faculty of Erciyes University, Kayseri, Turkey
}

\begin{abstract}
Herein, we present a 40 -year-old female case who was admitted to our hospital with the complaints of fever and a painful left leg. She had a five-month history of treatment with azathioprine and prednisolone for lupus nephritis. The patient was diagnosed with disseminated nocardiosis (nodular cutaneous lesions, bacteremia, brain abscesses, and a reticulonodular miliary tuberculosis-like infiltration) associated with Nocardia farcinica and was treated using linezolid, netilmicin, and ceftriaxone. This case is important as treatment of Nocardia infections remains week particularly when they involve the central nervous system and when they are sustained by highly drugresistant species such as Nocardia farcinica.
\end{abstract}

Key words: Disseminated nocardiosis; Nocardia farcinica; systemic lupus erythematosus.

Systemic lupus erythematosus (SLE) is a chronic inflammatory disease with an unknown etiology that affects the skin, joints, kidneys, lungs, nervous system, serous membranes, and organs of the body. Infections occur frequently in patients with SLE, and the high frequency and unusual spectrum of these infections can be attributed to the multiple disturbances of the immune function associated with SLE in combination with the effects of immunosuppressive therapy. In fact, there is increasing evidence that indicates that
Bu makalede, hastanemize ateş ve sol bacakta ağrı yakınmalarıyla başvuran 40 yaşında bir kadın olgu sunuldu. Hasta lupus nefrit nedeniyle beş ay boyunca azatioprin ve prednizolon tedavisi almıştı. Nocardia farcinica ile ilişkili yaygın nokardiyoz (nodüler kutanöz lezyon, bakteriyemi, beyin apsesi ve miliyer tüberküloz gibi retikülo nodüler infiltrasyon) tanısı konulan hasta linezolid, netilmisin ve seftriakson ile tedavi edildi. Özellikle merkezi sinir sistemi tutulumu olan ve Nocardia farcinica gibi ilaca karşı yüksek düzeyde dirençli suşların enfeksiyonu durumunda Nocardial enfeksiyonlarının tedavisi zor olmaktadır, olgu bu açıdan önem taşımaktadır.

Anahtar sözcükler: Yaygın nokardiyoz; Nocardia farcinica; sistemik lupus eritematöz.

opportunistic infections play a large role in the infectious mortality connected with SLE.

Nocardiosis is an uncommon, Gram-positive bacterial infectious disease that is typically opportunistic in nature. The incidence of nocardiosis has increased with the expansion of immunosuppressive therapy and improvement in laboratory diagnostic methods. It is classified based on the location and extent of the disease and is often found in the pulmonary and central nervous

\footnotetext{
Received: August 12, 2012 Accepted: February 18, 2013

Correspondence: Öztürk Ateş, M.D. Erciyes Üniversitesi Tıp Fakültesi Nefroloji Anabilim Dalı, 38039 Talas, Kayseri, Turkey.

Tel: +90 352 - 4379349 e-mail: dr.ozturkates@yahoo.com

(2013 Turkish League Against Rheumatism. All rights reserved.
} 
systems. In addition, nocardiosis is a cutaneous and disseminated disease. ${ }^{[1]}$ Disseminated nocardiosis is defined as involvement in two noncontiguous sites that may or may not include a pulmonary focus. ${ }^{[1]}$ Furthermore, Nocardia can disseminate from a pulmonary or cutaneous focus to virtually any organ. ${ }^{[2,3]}$ Herein, we present a case of disseminated nocardiosis in a SLE patient who was treated with difficulty.

\section{CASE REPORT}

A 40-year-old female with a five-month history of azathioprine and prednisolone usage due to lupus nephritis presented to our hospital with a fever and left leg pain. Upon admission, the patient tested positive for the Homans' sign in the left leg, and a nodular lesion was found on the right temporal scalp. However, the other physical findings were unremarkable. The laboratory findings revealed a white blood cell (WBC) count of $5,280 \mathrm{~mm}^{3}$, an ESR of $113 \mathrm{~mm} / \mathrm{h}$, and a C-reactive protein (CRP) level of $148 \mathrm{mg} / \mathrm{d}$. In addition, a EUROIMMUN Microplate ELISA test kit was utilized (EUROIMMUN Corporation Deutschland; Lübeck, Germany) showed that the anti-nuclear antibody (ANA) ratio of $>1: 1000$ and an anti-double stranded DNA (anti-dsDNA) rate of 125 . The patient's renal and liver functions were normal, and the chest $\mathrm{X}$-ray findings showed no abnormalities. Furthermore, Doppler ultrasonography (USG) detected no deep vein thrombosis (DVT), and the urine and blood cultures were negative for bacterial growth. Moreover, the Brucella agglutination test, viral hepatitis serology test, and enyme-linked immunosorbent assay (ELISA)

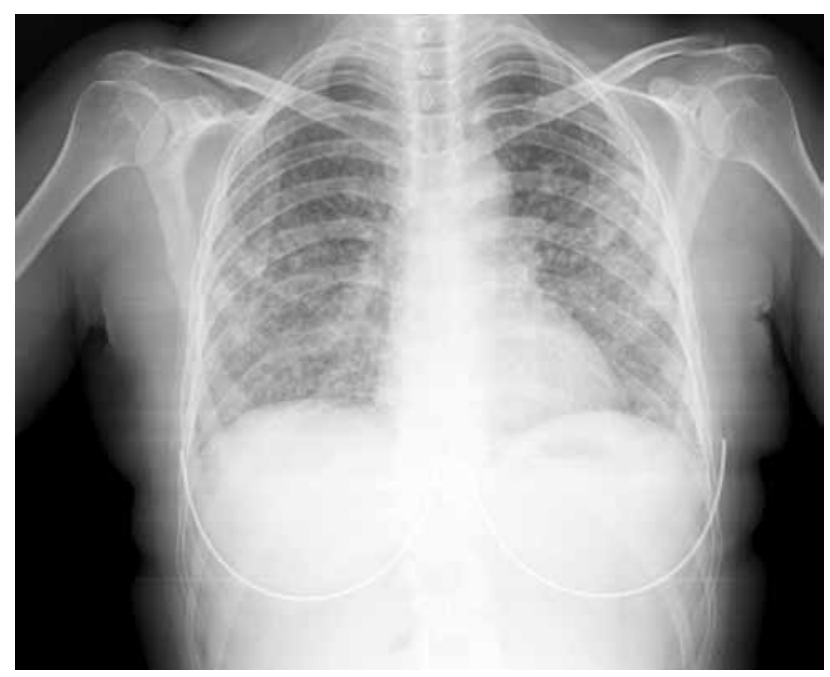

Figure 1. Chest X-ray showing the prevalence of miliary infiltration. test for human immunodeficiency virus (HIV) were also all negative. However, the patient did have a fever of an unknown origin.

Drainage of the right temporal scalp nodular lesion yielded purulent material and showed Gram-positive bacilli. It later grew nocardial infection, but the specific species was unidentified because our hospital's laboratory could not make that determination. Daily doses of trimethoprim-sulfamethoxazole (TMP-SMX) $15 \mathrm{mg} / \mathrm{kg}$ were started. The azathioprine treatment was withdrawn, and the prednisolone dosage was decreased from $40 \mathrm{mg} /$ day to $8 \mathrm{mg} /$ day. In addition, the patient's blood cultures grew beaded, branching Gram-positive rods which were identified as nocardial infection, and high-dose ceftriaxone treatment (4 g/day) was added to the treatment regimen. Five days later, she suddenly developed dyspnea and a cough, and a chest X-ray showed prevalent miliary infiltration (Figure 1). Additionally, urgent thoracic computed tomography (CT) showed miliary nodular infiltration [miliary tuberculosis (TB)-type pattern that appeared to indicate an infection]. Therefore, a bronchoscopy was performed, but Gram staining of the broncoalveolar lavage (BAL) specimen showed no nuclear neutrophils, microorganisms, or acid-fast bacilli.

The polymerase chain reaction (PCR) tests for $\mathrm{TB}$ and cytomegalovirus (CMV) were negative, and the BAL specimen cultures were negative for bacterial, fungal, and mycobacterial infection.

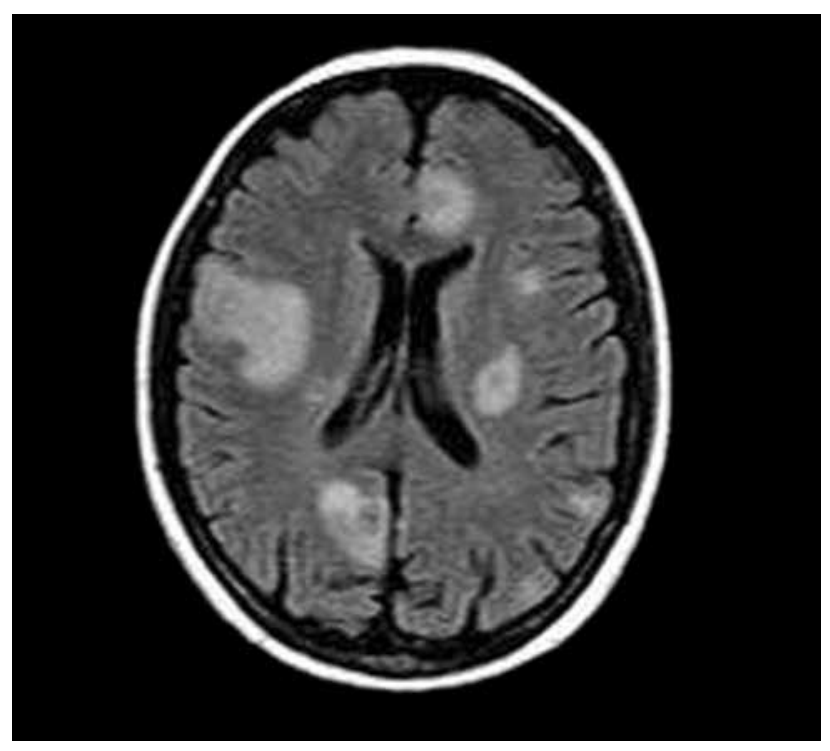

Figure 2. Contrast-enhanced magnetic resonance imaging showing multiple abscesses. 
Cranial CT showed hyperdense mass lesions, and contrast-enhanced cranial magnetic resonance imaging (MRI) detected multiple hypodense nodular lesions that were abscess-like (Figure 2) and ring enhancing in the frontal mesencephalon region and cerebella regions. The results for toxoplasma immunoglobulin (Ig) M and IgG were also negative. Based on these findings, the patient's treatment was changed to linezolid and ceftriaxone. One month later, the patient's dyspnea had improved, and the lung infiltration was reduced. The patient was then discharged from the hospital with a prescription for oral TMP-SMX and cefixime treatment; however, a week later, she was readmitted with increased dyspnea and a $38.5{ }^{\circ} \mathrm{C}$ fever. On admission, we observed a seizure and left-sided hemiparesthesia; hence, linezolid, ceftriaxone, levetiracetam, and phenytoin were started. Cranial MRI showed a progression of the abscess lesions, especially in the right frontal region $(2.5 \mathrm{~cm}$ diameter) and midline shift of the ventricle; therefore, urgent surgical decompression of the abscess was performed. A post-surgical examination of the blood cultures was performed at a private laboratory, and it showed Nocardia farcinica (N. farcinica) infection via a sequencing analysis of the $16 \mathrm{~S}$ rRNA gene of isolates. The N. farcinica antibiogram was resistant to TMPSMX, ampicillin, and imipenem, so metilmicin was added to the patient's treatment. A good outcome was achieved following three months of intravenous treatment as the patient's brain abscess regressed. However, the left hemiparesis persisted.

\section{DISCUSSION}

The genus Nocardia includes more than 80 species, at least 33 of which cause disease in humans. ${ }^{[4]}$ Infection is usually acquired opportunistically via inhalation, direct inoculation, or attacks. Predisposing conditions include a compromised immune response for any reason, HIV infection, hematological malignancies, severe SLE, solid tumors, or long-term steroid or other immunosuppressive therapies. ${ }^{[5]}$ Nocardia bacteremia is a rare presentation. In the present case, the nocardial infection originated on the skin and then spread hematogenously to the lungs and brain, with the lungs being the primary site of this type of infection in more than $66 \%$ of cases. ${ }^{[2]}$ However, our patient did gardening and may have had cutaneous contact. Pulmonary nocardiosis can manifest in conjunction with empyema and can coexist with pulmonary and extrapulmonary TB. Pneumonia, nodules, and abscess have all been described in the literature, but there have been no reports of cases with the miliary TB-type pattern that was present in our patient. ${ }^{[6]}$

Cerebral nocardiosis constitutes the most severe form of nocardial infection, and about $71 \%$ of the patients with this condition also have a coexisting nocardial infection. ${ }^{[7]}$ The treatment options for nocardial CNS involvement include antimicrobial therapy alone, freehand or stereotactic aspiration/ biopsy, and a craniotomy plus enucleation along with antibiotic therapy. It has been reported that all abscesses of bigger than $2.5 \mathrm{~cm}$ should be aspirated, regardless of a patient's immune status. ${ }^{[8]}$ In our case, the nocardial infection in the brain was treated both medically and surgically.

Although the reviews in the literature have recommended TMP-SMX as the therapeutic drug of choice for treating nocardial infections because of its good tolerability and capacity to penetrate the cerebrospinal fluid, sulfonamide-resistant nocardial infections have been reported in many countries. ${ }^{[9,10]}$ Trimethoprim-sulfamethoxazole susceptibility varies geographically and TMP resistance ranges from a low of $32 \%$ (Nocardia brevicatena) to a high of $93 \%$ (N. farcinica). Alternative therapies include a combination of amikacin and imipenem, linezolid, third-generation cephalosporin, or minocycline. ${ }^{[1]}$ In this case, the nocardial infection was resistant to imipenem and TMP-SMX; thus, a combination of ceftriaxone and linezolid was initiated. Linezolid crosses the bloodbrain barrier and has excellent bioavailability. In vitro activity involving the use of linezolid against Nocardia spp. has been reported in several studies. ${ }^{[12]}$ To date, 15 cases of nocardiosis treated with linezolid have been published. ${ }^{[13]}$ We initiated treatment with this combination and netilmicin was added because of the progression of the brain abscess. Nocardial infection in patients with SLE has been treated with good results. ${ }^{[14]}$

Although the incidence of nocardiosis appears to be increasing, it remains a rare opportunistic infection. Nocardia farcinica infection is associated with a high risk of dissemination and antibiotic-resistance; therefore, it has a high mortality rate. Clinicians should be aware of the possibility of aggressive nocardiosis in patients using immunosuppressive agents, and low-dose prophylaxis should be considered. 


\section{Declaration of conflicting interests}

The authors declared no conflicts of interest with respect to the authorship and/or publication of this article.

\section{Funding}

The authors received no financial support for the research and/or authorship of this article.

\section{REFERENCES}

1. Lerner PI. Nocardiosis. Clin Infect Dis 1996;22:891-903..

2. Lederman ER, Crum NF. A case series and focused review of nocardiosis: clinical and microbiologic aspects. Medicine (Baltimore) 2004;83:300-13.

3. Kontoyiannis DP, Ruoff K, Hooper DC. Nocardia bacteremia. Report of 4 cases and review of the literature. Medicine (Baltimore) 1998;77:255-67.

4. Brown-Elliott BA, Brown JM, Conville PS, Wallace RJ Jr. Clinical and laboratory features of the Nocardia spp. based on current molecular taxonomy. Clin Microbiol Rev 2006;19:259-82.

5. Kahn FW, Gornick CC, Tofte RW. Primary cutaneous Nocardia asteroides infection with dissemination. Am J Med 1981;70:859-63.

6. Hwang JH, Koh WJ, Suh GY, Chung MP, Kim H, Kwon OJ, et al. Pulmonary nocardiosis with multiple cavitary nodules in a HIV-negative immunocompromised patient. Intern Med 2004;43:852-4.
7. Mamelak AN, Obana WG, Flaherty JF, Rosenblum ML. Nocardial brain abscess: treatment strategies and factors influencing outcome. Neurosurgery 1994; 35:622-31.

8. Obana WG, Rosenblum ML. Surgery for intracranial infections. In: Post KD, Friedman ED, McCormick P, editors. Postoperative complications in intracranial neurosurgery. New York: Thieme; 1993. p. 146-56.

9. Tremblay J, Thibert L, Alarie I, Valiquette L, Pépin J. Nocardiosis in Quebec, Canada, 1988-2008. Clin Microbiol Infect 2011;17:690-6.

10. Uhde KB, Pathak S, McCullum I Jr, Jannat-Khah DP, Shadomy SV, Dykewicz CA, et al. Antimicrobial-resistant nocardia isolates, United States, 1995-2004. Clin Infect Dis 2010;51:1445-8.

11. Wallace RJ Jr, Steele LC, Sumter G, Smith JM. Antimicrobial susceptibility patterns of Nocardia asteroides. Antimicrob Agents Chemother 1988;32:1776-9.

12. Glupczynski Y, Berhin C, Janssens M, Wauters G. Determination of antimicrobial susceptibility patterns of Nocardia spp. from clinical specimens by Etest. Clin Microbiol Infect 2006;12:905-12.

13. Tanioka K, Nagao M, Yamamoto M, Matsumura Y, Tabu $\mathrm{H}$, Matsushima A, et al. Disseminated Nocardia farcinica infection in a patient with myasthenia gravis successfully treated by linezolid: a case report and literature review. J Infect Chemother 2012;18:390-4.

14. Mok CC, Yuen KY, Lau CS. Nocardiosis in systemic lupus erythematosus. Semin Arthritis Rheum 1997;26:675-83. 